\title{
Resilience of Primary Food Production to a Changing Climate: On-Farm Responses to Water-Related Risks
}

\author{
Tim Hess *® Jerry Knox®, Ian Holman $®$ and Chloe Sutcliffe \\ School of Water, Energy and Environment, Cranfield University, Cranfield, MK43 0AL Bedfordshire, UK; \\ j.knox@cranfield.ac.uk (J.K.); i.holman@cranfield.ac.uk (I.H.); c.sutcliffe@cranfield.ac.uk (C.S.) \\ * Correspondence: t.hess@cranfield.ac.uk; Tel.: +44-123-4750-111
}

Received: 2 June 2020; Accepted: 27 July 2020; Published: 30 July 2020

\begin{abstract}
Water is a fundamental component in primary food production, whether it be rainfall, irrigation used to water crops, or for supplying drinking water for animals, while the amount of water in the soil determines it capacity to support machinery and animals. We identify that UK agriculture is exposed to five main water-related risks: agricultural drought, scarcity of water resources, restrictions on the right to abstract water, excess soil water, and inundation. Projected milder, wetter winters and hotter, drier summers by the end of the century will change the frequency, persistence, or severity of each of these risks. This paper critically reviews and synthesizes the scientific literature on the impact of these risks on primary food production and the technological and managerial strategies employed to build resilience to these changing risks. At the farm scale, the emphasis has been on strategies to build robustness to reduce the impact of a water-related risk. However, collaborative partnerships allow for a more optimal allocation of water during times of scarcity. Enhancing cross-scale interactions, learning opportunities, and catchment-scale autonomy will be key to ensuring the agricultural system can build adaptive and transformational capacity.
\end{abstract}

Keywords: drainage; drought; flooding; irrigation; water resources

\section{Introduction}

At a conceptual level, resilience refers to the ability of a system to cope well with changing circumstances, including both predictable and unpredictable shocks and stresses. As such, resilience is a key component of sustainability [1]. The term resilience has become extensively used in the context of agricultural production, climate change, and water security, but often without clear definition. Here, we adopt the definition of resilience as the "ability ... to anticipate, absorb, accommodate, or recover from the effects of a hazardous event in a timely and efficient manner" [2] (p. 34). The concept may be applied either to an entire system or components within a system, and to all hazardous events or a sub-set of events. Resilience applied to particular components of the system and a particular sub-set of events is referred to as 'specified resilience' [3] and must be qualified by response to the specific questions 'resilience of what', and 'resilience to what?' [4].

Climate change is likely to result in a range of pressures on UK agriculture, including, for example, extreme temperatures, increased frost risk, storm damage, and drought risk [5]. In this paper, we consider the resilience of an agricultural system's capacity to produce food crop and livestock outputs that contribute to the UK food supply and exports (of what) in the face of climate change. We only consider food production up to the farm-gate and do not take into account any downstream impacts on food manufacturing/processing, retail, consumption or food waste.

Water is a fundamental component in agricultural production, whether it be rainfall or irrigation used to water crops or for supplying drinking water for animals. The reliable supply of sufficient water of an adequate physical, chemical, and biological quality is essential for supporting national food 
production and food security needs. Five main water-related risks to food production from agriculture can be identified (Figure 1), the frequency, persistence, or severity of which are projected to change by the end of the century due to changes in climate. A sustained period of rainfall deficit (1) can impact rain fed cropping and grassland productivity. If prolonged, a scarcity of water resources may develop, leading to the failure of private water supplies (2) and/or restrictions on the right to abstract water from surface or groundwater sources (3). Meanwhile, too much rainfall results in excess soil water (4), reducing oxygen availability and the workability and trafficability of the soil. Finally, agricultural land can be subject to the inundation of water over-spilling from ditches, rivers, and streams (5) during periods of intense rainfall.

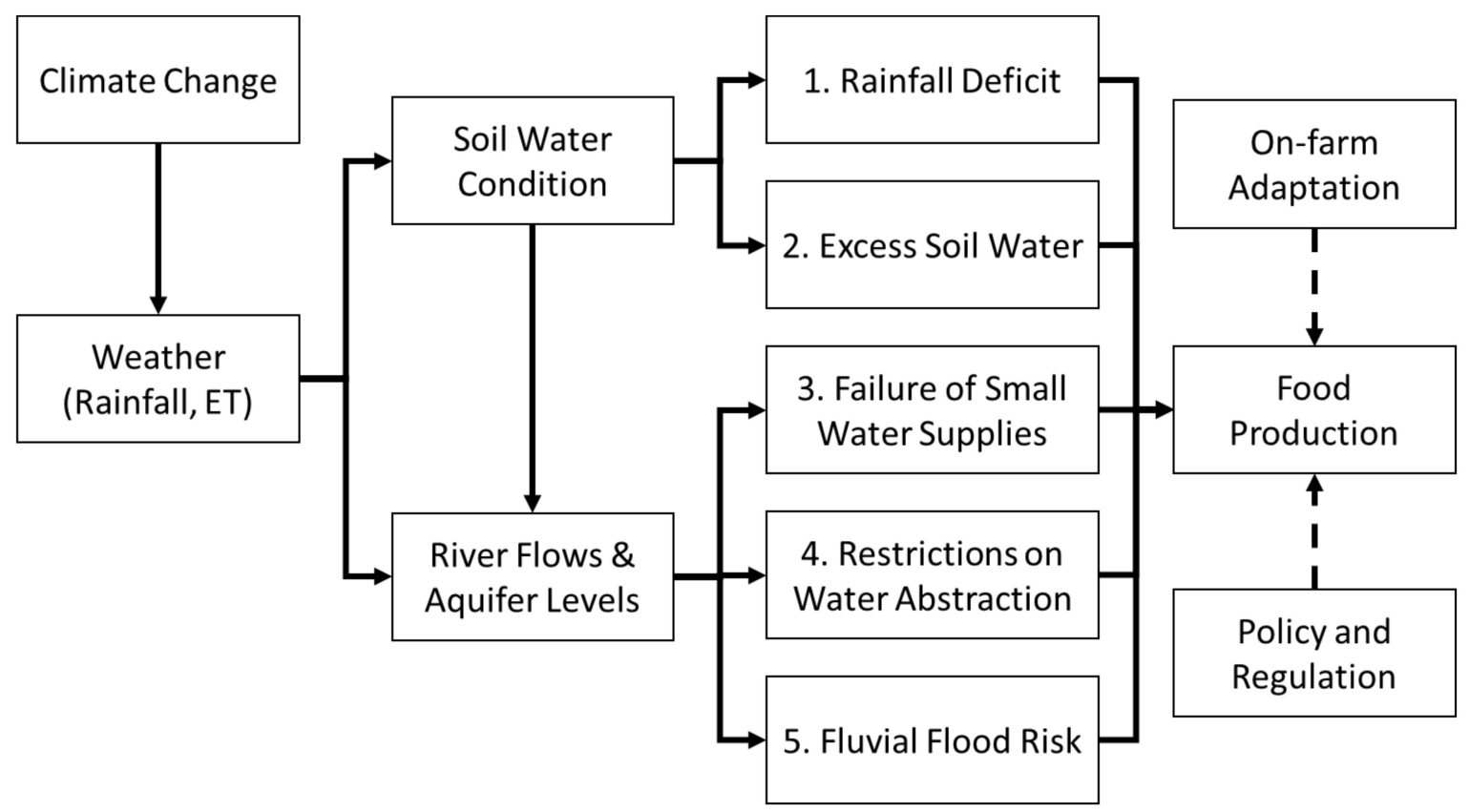

Figure 1. Climate change impacts on water-related risks and agricultural food production.

This paper therefore explicitly focuses on 'water-related risk' (to what), over timeframes ranging from short-term (next 10 years) to the next-century. The geographical focus is on the UK (although some of the data only refer to England, or England and Wales, due to the way they are collected and reported). However, the findings have much broader international relevance to mixed agricultural systems in temperate climates with supplementary irrigation.

Agricultural systems in the UK have become well adapted to their catchment-scale combinations of soils and climate [6], infrastructure and resource allocation. Climate change is projected to result in different distributions of extreme weather events, which, through their impact on soil moisture and hydrology, will impact on the ability of the agricultural sector to continue to produce the same range, quantity and quality of food. The latest projections from the UK Climate Impacts Programme 2018 [7] has projected an increased probability of milder, wetter winters and hotter, drier summers (Figure 2) along with an increase in the frequency and intensity of extremes. These changes are projected to increase water scarcity and rainfall variability with an increased frequency, duration, and severity of droughts as well as increased impacts from very wet years [8].

We are therefore concerned here with the actions that may be taken by stakeholders to increase the resilience of agriculture to continue to produce food in the face of changing water-related risks. These actions may help to absorb the impact and resist change (robustness or persistence), to return to normal more quickly following shock, to undertake preparations to limit the impacts of such an event in future (recovery or adaptability), or to change to a different condition that is at least as desirable as the original (re-orientation or transformability) $[1,3,9]$. Through a critical review and synthesis of the 
scientific literature, this paper evaluates the range of on-farm responses, or adaptations, necessary to build increased resilience to these emergent risks.

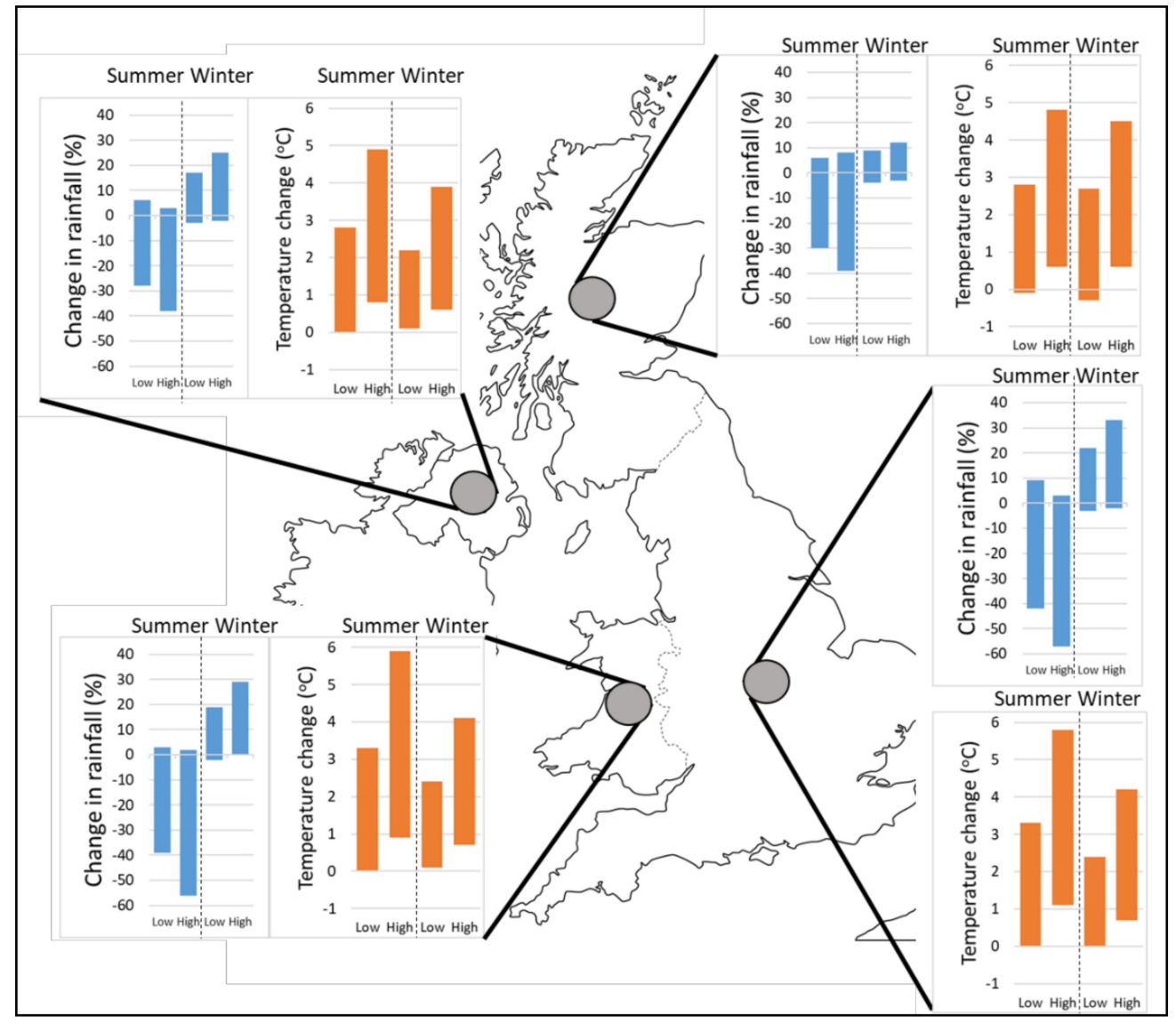

Figure 2. Projected changes in summer and winter rainfall and temperature for indicative central locations in each UK country, from UK Climate Impacts Programme 2018 [7] for High and Low emissions scenarios. All results are for the 10th-90th percentile range for the 2060-2079 period relative to $1981-2000$.

\section{Water-Related Risks to Agriculture}

\subsection{Rainfall Deficit}

In the UK, most (99\%) of the agricultural land area is rain fed. In most years, evapotranspiration generally exceeds rainfall from late spring onwards with soil moisture deficits (SMD) then developing over the summer months and peaking by autumn. During a period of unusually low rainfall and/or high evapotranspiration (meteorological drought) the SMD increases and when it becomes sufficiently extreme to impact on plant (including crops, fodder and grazing) growth, it is referred to as an agricultural drought [10].

Through a reduction in summer rainfall and an increase in potential evapotranspiration, climate change is projected to result in warmer, drier summers, higher potential SMDs and increased agricultural drought risk [5]. The two most important impacts on rain fed cropping are likely to be changes in productivity (yield and quality) and land suitability [11,12]. For example, increasing agricultural drought risk coupled with extreme temperatures is projected to negatively affect wheat yield [13] and reduce the area of land that is currently suited to rain fed potato production [14].

The potential impacts of increasing agricultural drought risk in a catchment depend on the agro climatic conditions and soil type [13]. Those areas where rainfall is only just sufficient and soils have low water holding capacity are most vulnerable to increased drought risk. Similarly, some crops are more 
vulnerable than others. For example, rye and triticale are more tolerant of drought, and barley more sensitive, than wheat [15]. Some vegetable crops, particularly those grown on low moisture retentive soils and with shallow rooting systems are also vulnerable to drought risk. It is difficult to separate the impact of rainfall deficit from restrictions on water abstractions (see below), but dry weather between 2010 and 2012 was estimated to have caused losses of $£ 400$ million to UK agriculture [16] with losses in 2012 valued at $£ 72$ million to irrigated potato production in England [17].

Rial-Lovera at al. [18] reviewed the range of agricultural practices that could help farmers adapt to changes in climate. They can be considered under the main headings of crop and soil management. Crop management responses to build resilience to agricultural drought include earlier planting to avoid the coincidence of periods of high drought risk with most sensitive growth stages and selecting more drought tolerant crops and varieties, including those with deeper rooting characteristics, varieties specifically bred for drought tolerance, and varieties adopted from regions with greater drought risk. Higher spring temperatures may facilitate opportunities for early planting and the adverse effect of increased drought risk on yield may be at least partially be compensated for by earlier maturation and the fertilisation effects of elevated $\mathrm{CO}_{2}$ concentration levels on photosynthesis [19,20]. Soil management responses include reduced, or no-tillage systems to encourage soil moisture conservation [21], increasing soil water holding capacity through the addition of organic amendments [22,23], and soil surface modification to maximise rainfall infiltration [24,25].

Farmers can also increase their robustness to drought risks by supplementing rainfall with irrigation. It is likely that with increasing drought risk and rainfall uncertainty, supplementary irrigation may become more widespread and economically viable on crops such as wheat [13] and grass that have historically always been rain fed.

\subsection{Restrictions on Water Abstractions for Spray Irrigation}

Although most crops in the UK are rain fed, supplementary irrigation is critical for high-value field scale vegetable, salad, soft fruit and potato cropping with an estimated added value of $£ 665$ million in a dry year (England and Wales) [26]. Outdoor irrigation of field crops accounts for $42 \%$ of direct abstraction for agriculture (with a further $40 \%$ for drinking water for livestock) [27]. Just over half (54\%) of the volume of irrigation water is withdrawn directly from rivers and streams, with groundwater (41\%) making up most of the remainder [27]. Public mains water $(\sim 1 \%)$ is only used on small horticultural units (protected edibles cropping) where water quality (notably microbiological) and reliability of supply are important factors.

All direct abstractions for agriculture from surface and groundwater resources $\left(\geq 20 \mathrm{~m}^{3} / \mathrm{d}\right)$ are subject to regulatory controls and most are controlled through time-limited licences with prescribed conditions ('hands-off flows', or 'hands-off levels' for surface and groundwater, respectively). In addition, during periods of hydrological drought (extreme low river flows or groundwater levels) agricultural abstractors with 'spray irrigation' licences may be subject to emergency restrictions on the timing or volumes of water abstracted under Section 57 of the Water Resources Act [28], so-called Section 57 restrictions. This provides the government with powers to implement either partial or total bans on abstraction, both of which can have major financial consequences for agricultural food production $[29,30]$.

Climate change is projected to increase the risk of low river flows and reduced ground water levels [5] and increase the demand for supplemental irrigation [31]. Therefore, the combination of reduced water availability and increased demand means that restrictions on abstraction will become more severe, frequent and longer in the future [32]. If irrigation demand exceeds the available supply, then farmers will make decisions about prioritizing crops that will give the highest financial returns to water at the particular growth stage, thus reducing output of some crops to limit overall financial impact to the business [33].

Rey, Holman and Knox [33] also reviewed how UK irrigated farming businesses might adapt to future drought risks. Resilience responses can broadly be divided into those that reduce water demand 
and those that increase available water supply. Not all withdrawn water ends up being productively used by the growing crop. This is often referred to as 'irrigation efficiency' (or, more correctly, 'water productivity') [34]. In contrast to irrigation globally, irrigation in the UK is relatively efficient, with hose reels fitted with and rain guns or booms, which account for 93\% of irrigation in the UK [27], typically operating at about 70-80\% efficiency.

Water productivity can be improved in a variety of ways, including techniques to reduce non-productive evaporation (e.g., weeding, mulching), drainage and runoff losses (e.g., using objective or scientific scheduling rather than subjective methods such as feeling the soil), as well as conveyance and distribution losses (e.g., equipment selection, infrastructure maintenance) [35]. In a survey of 66 horticultural farms in England, Gadanakis et al. [36] found that, on average, water requirements could be reduced by $35 \%$ to achieve the same output (gross margin). The use of recycled water, micro-irrigation systems and decision-support tools were associated with higher water use efficiency. However, experience world-wide has shown that when irrigation efficiency is increased, farmers tend to use the extra 'saved' water released to increase their irrigation command areas rather than reduce water withdrawals [37].

During drought conditions, many irrigated holdings are also constrained by the capacity of their irrigation infrastructure. Traditionally, irrigation systems in the UK were designed to apply a peak rate of $25 \mathrm{~mm}$ ( $1 \mathrm{inch}$ ) every 10 days [38] (i.e., an average of $2.5 \mathrm{~mm} / \mathrm{d}$ ), however, peak evapotranspiration rates can reach $5 \mathrm{~mm} / \mathrm{d}$ (e.g., in the summer of 2018). Where water is still available, farmers would need to invest in greater irrigation capacity to meet higher peak rates of water use and thus be more robust in the face of water shortages.

Demand for water for irrigation is concentrated in the driest areas, particularly in south and eastern England where many catchments are already fully licensed for summer abstraction. Consequently, demand for irrigation tends to be greatest in catchments that are already under water stress. About half of all potatoes, field vegetables and soft fruit holdings (England and Wales) are located in catchments defined as either having 'no (more) water available' or as being 'over- licensed', whilst nearly a fifth are in catchments defined as being 'over-abstracted' [39]. In some catchments there is still water available for abstraction during high flows. On-farm storage provides the opportunity to take additional water during periods of high flow for use in the summer and increase the security of water supply. In 2010, $34 \%$ of the volume of water licensed for spray irrigation was drawn from winter storage and this proportion is steadily increasing [40]. However, the capital costs of reservoir construction, the planning process and 'land-take' are all barriers to investment [40].

Where there is no opportunity to increase summer abstraction, growers seek to make the best use of water that is already licensed. Many spray irrigation licences are unused, or under used, even in drought conditions [32]. For historical reasons, the licence holder may no longer require the volume of water licensed but may be keen to retain the water right-as it enhances the value of the land and provides for future business cropping flexibility. Farmers are able to share or 'trade' water in order to make productive use of under, or un-used licences although legislative barriers still make trading cumbersome and slow [33]. Current provisions in water regulation for trading are under review with plans to reduce the transaction times required for trading and increase the flexibility of trading options.

Established lines of communication, trust and good relationship with abstractors can significantly help the water regulatory authority balance the needs of farmers with public water supply, industry and sustaining the environment during drought events. In recent years, the regulator has developed a more proactive approach to communicating with farmers during emergent drought conditions which has allowed irrigators to adapt their management to the changing conditions [41]. Abstractors can work collectively through water abstractor groups which provide a mechanism for interaction between abstractors to share water resources, exchange best practice [40] and negotiation with the regulator [42]. Improved drought monitoring and forecasting would also help to reduce the financial impact of a drought and increase resilience to future droughts [6]. 
Most of the water used for irrigation is withdrawn from rivers, streams or groundwater [27] which are subject to seasonal variation and vulnerable to drought. Alternative water supplies, such as industrial wastewater and treated sewage effluent, would provide a more reliable supply of water. However, the legislation regarding the re-use of treated sewage effluent for crop irrigation in the UK is very restrictive [43] due to concerns regarding the impacts of microbiological pathogens on public health and the capital investment required is substantial [40].

In addition, the crop and soil management strategies applied to rain fed cropping can also be applied to irrigated crops. It is possible that farmers in most water-stressed catchments would have to switch to rain fed cropping, and some have suggested that there may be a gradual northward shift in production of water-intensive crops such as potatoes and field-scale vegetables to areas with suitable land and into catchments where there are available water supplies [12].

\subsection{Failure of Private Water Supplies}

Over half of the water used on farms (in England and Wales) is used for drinking water for livestock (41\%), general farm activities (such as wash-down) $(13 \%)$, agrochemical spraying (4\%) and non-agricultural farm uses (18\%) [27]. Although most of farms have access to public water supply [44], a large volume of water is still abstracted for non-irrigation uses. Many of these are small water supplies from streams, ponds and shallow groundwater that withdraw less than the de minimis 20 $\mathrm{m}^{3} / \mathrm{d}$ and do not require an abstraction licence. Moreover, they are also not subject to abstraction restrictions during drought events.

Private water supplies are particularly important for livestock farms for drinking water which accounts for $79 \%$ of the total water requirement of dairy cattle and $>90 \%$ of the water requirement for pigs, sheep and poultry [45]. Although water demand for livestock production is concentrated in the wetter, more upland catchments in the UK, and in water company areas that are not seriously stressed [46], small water supplies are subject to increasing risk of 'drying up' due to climate change and there is no obligation on water companies to supply water [47]. It is difficult for livestock farmers to respond to the short-term failure of small water supplies. In an extreme situation, livestock farmers would need to reduce herd size by either slaughtering or sale of stock.

To build resilience to increasing drought risk, livestock farmers also seek ways to increase the efficiency of water use (i.e., water use per head) on the farm. There is little scope for reducing livestock drinking water apart from changing the animal's diet or the ambient temperature of animal housing. However, modifying practices, changing water infrastructure and fixing leaks can significantly reduce water withdrawals [48]. Using water from alternative sources can reduce vulnerability to water shortages. Rainwater harvested from roofs of farm buildings, or water recycled water after it has been used for another process, can be used for uses that do not require high quality water, such as yard and equipment washing, or to top up a farm reservoir. However, such sources may not be of suitable quality for livestock drinking water.

\subsection{Excess Soil Water}

Excess soil water leads to reduced soil oxygen and temperatures, lower nutrient availability and therefore reduced plant growth rates and increased risk of plant and animal diseases. The water content of the soil also determines its mechanical properties and determines whether critical farm operations, such as soil tillage, pest control, harvest and stock grazing can take place in a timely manner. Inadequate consideration of soil water in agricultural management may result in compaction from machinery trafficking and poaching from animals leading to loss of soil structure and increased risk of rainfall runoff [49].

An increased frequency of extreme rainfall events has been observed over the last 50 years [50] and is projected to have a greater frequency [51] and intensity [52] in the future. Increased winter rainfall would lead to increased risk of soil waterlogging and reduced trafficability, although drier summers may reduce the period of wet soils. Much of the intensively managed agricultural land, 
particularly arable land in eastern England relies on sub-surface drainage to manage excess water and optimise soil water conditions for plant growth and trafficability. Much of the existing drainage infrastructure on-farm was installed in the post-war period and benefited from grant aid. An estimated 2.4 M ha were drained between 1951 and 1993 [53]. However, since the withdrawal of grant aid, the rate of installation of new drainage has decreased markedly, as has the maintenance of existing systems. To reduce the impacts of higher rainfall amounts and intensities on waterlogging would require significant capital investment in upgrading existing field drainage systems.

\subsection{Fluvial Flood Risk}

About $8 \%$ of the agricultural land in England is at risk of flooding from rivers (fluvial flooding). Inundation not only causes waterlogging, but also results in loss of crop, livestock and equipment, and deposition of debris and contaminants onto the land. The resulting loss of production and additional costs for the 2007 summer floods [54], 2010 spring floods [55], and the winter floods of 2014 [56] ranged from $£ 400-£ 1400$ per hectare. Losses were higher for spring and summer events, long duration flooding and where higher value crops were affected. With more intense rainfall events, flooding of agricultural land is projected to become frequent in the UK [5] as for most countries in Central and Western Europe [57].

About half of the agricultural land at risk of flooding has some form of flood defence, which saves $\sim £ 5 \mathrm{~m}$ annually in damage costs from flooding from rivers and the sea [58]. An effective arterial drainage system also helps evacuate water quickly after a flood and reduce the damages. However, there has been little new investment in defences for agriculture and in some places, defences have been allowed to deteriorate in order to create additional flood storage capacity.

If flood risk to agricultural land cannot be reduced by protection, then damages can be minimised by careful land use selection. Horticultural and intensive arable land is most sensitive to flooding and a single event at the wrong time of the year, can result in the complete loss of yield. Cereals are more tolerant and improved grassland may tolerate flooding up to once every other year. Consequently, most agricultural land in England that is exposed to the risk of frequent $(<3$ year return period) flooding is under grassland [58].

In most farms, the land prone to fluvial flooding is generally a small proportion of the farm area, hence, for livestock farms, the impact of a flood can be reduced if there is enough conserved forage (hay or silage) to feed animals elsewhere whilst flooded fields are unfit for grazing [54,55]. If farmers are given sufficient warning, they have time to move stock and machinery from affected land and reduce the impact of flooding [54]. Although many rural areas still have relatively poor mobile phone and broadband coverage, warnings can be issued through land lines and via mainstream media.

\section{Discussion}

This review has shown how climate change may impact agriculture and food production in the UK through five water-related risks that are all projected to increase in frequency, intensity or persistence. Socio-ecological resilience is widely held to refer to three capacities; (i) the capacity to absorb shocks and maintain function, (ii) the capacity to reorganise system components and learn in order to adapt, and (iii) ultimately the capacity to shift into a new mode of system behaviour when continuing along the same trajectory becomes untenable [3,59]. This review has identified four approaches to increasing the resilience of food production in the face of increasing water-related risks due to climate change (Figure 3 ).

Reduce probability: The probability of certain water-related risks (e.g., fluvial flooding) may be reduced by de-coupling production from the source of the risk (e.g., by building flood defences for agricultural land or moving cropping into protected environments). However, the high cost of investment can only be justified for the protection of very high value crops (e.g., salad vegetables) or, in the case of flooding, large areas at risk. Undertaking such investments can lock growers into the production of higher value produce which often entails greater risk exposure. Such lock-in reduces the flexibility for diversifying crop profiles, downscaling production or reverting to lower risk, lower 
value production strategies in future. The long run resilience benefits of such investments therefore need to be carefully scrutinized. The probability of other water-related risks (e.g., agricultural drought or excess soil water) may be reduced by appropriate soil management. For example, the addition of organic matter to increase soil water holding capacity reduces drought risk, whereas cultivation to restore soil structure and improve drainage reduces risks from excess water. Soil management is a 'low cost' option and yields benefits in most years.

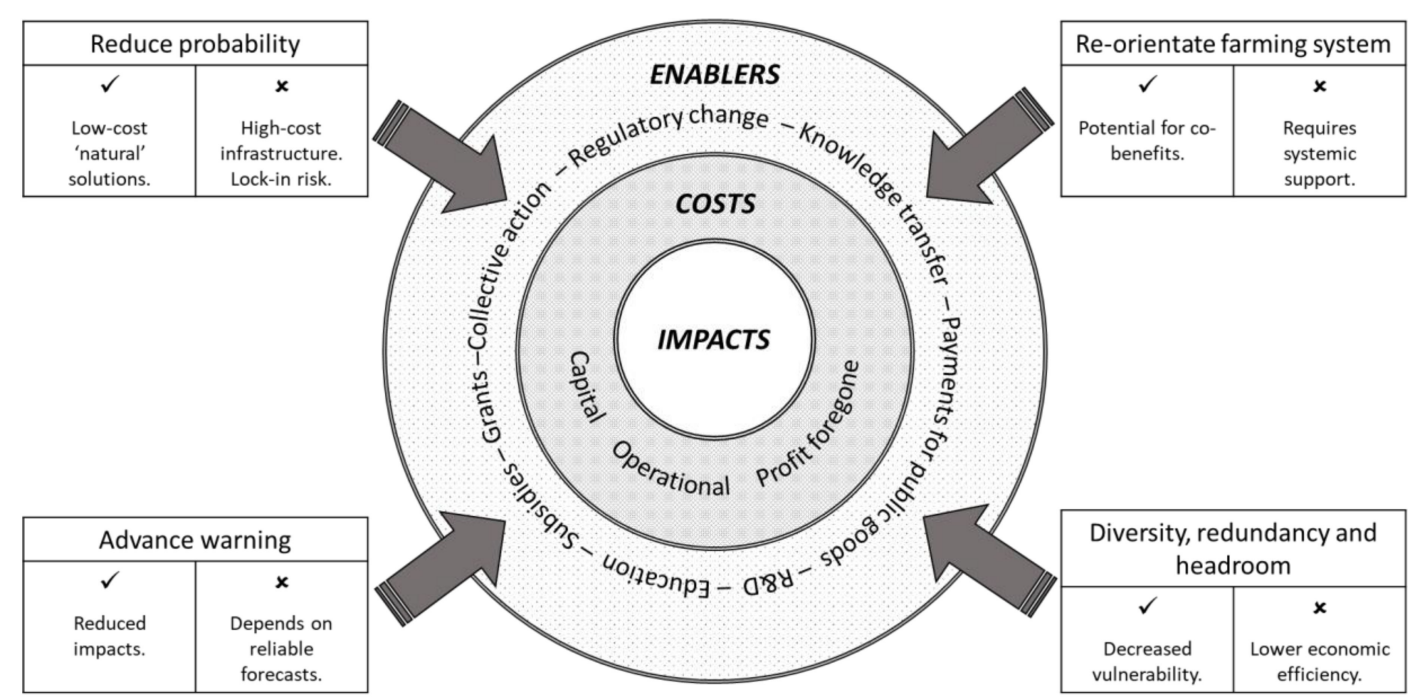

Figure 3. Approaches to increasing the resilience of food production in the face of increasing water-related risks due to climate change.

Increase robustness to persist: Most of the resilience strategies reviewed have focused on robustness, i.e., actions that have been taken to allow the system to absorb the shock of a water-related risk and allow food production to continue, as far as possible, unaffected. This tendency mirrors resilience actions in many sectors outside agriculture, with actions predominantly focusing on minimising impacts of near-term, high probability risks, whilst more uncertain, longer term threats are neglected [1]. Robustness is generally achieved through building diversity, redundancy or headroom [60]. Diversity allows one resource to substitute for another during an event [61]. For example, using conserved fodder to substitute for grazing land during a flood or an alternative water supply to substitute for one that has been disrupted due to drought. More diversity in cropping regimes can spread vulnerability, whilst greater crop homogeneity loads vulnerability to particular water risks, incurring higher losses when such hazards occur. However, market pressures that depend on economies of scale mean that in much field-scale agriculture, opportunities for diversifying production regimes are limited. Genetic diversity within crop cultivars also reduces risk-loading on particular vulnerabilities, but again is at odds with produce uniformity, which is a requirement for mechanical processing $[62,63]$. Redundancy implies resources that are not fully utilised in normal times, such that they can be drawn on in times of shock [64]. This may be through redundancy of equipment (e.g., additional irrigation equipment), that can be utilised during an extreme event, or through increasing the headroom between supply and demand such that increases in demand and/or reductions in supply do not impact the farm operations. Where a resource is limited in supply, increasing efficiency of resource use (e.g., a more efficient irrigation or animal drinking system) will allow demand to be met in a drier year by decreasing demand and increasing the system headroom that can be utilised during an event, providing that any headroom achieved by increasing efficiency in resource use is preserved rather than diverted into production expansion.

For diversity and redundancy to be effective in building resilience to water-related risks, there must be spare capacity during normal times that can be drawn upon in times of need. This implies an 
opportunity cost [65] (e.g., the depreciation cost of an irrigation machine, or the irrigation potential of unused water stored in a reservoir, that are not used in most years) that must be justified by the penalties avoided in an extreme event (although pre-emptively calculating the cost of uncertain future penalties is difficult). As indicated above, where opportunity costs are high there is a tendency over time to expand production or otherwise utilise the 'spare' resources, such that redundancy is diminished, and vulnerability increases. In this way, strategies that enhance economic efficiencies in agricultural production, which often dominate farm business decision-making given highly competitive operational environments, may diminish system redundancy and diversity and thereby erode resilience to water risks.

Facilitate recovery and increase adaptability: Increasing system robustness, or the capacity to maintain stable outputs by absorbing shocks, is often a focus for specified resilience, but when such activities predominate, general resilience to more infrequent types of system disturbance can suffer [3]. As such, authors have highlighted the importance that resilience strategies focus on novelty, reorganization and cross-scale interactions [66]. When sufficient robustness cannot be achieved at a reasonable cost, farmers then seek to minimise the financial impact of the shock and facilitate recovery. Some actions can shorten the duration of the event (e.g., pumping and effective arterial drainage to remove excess water), but in many cases farm-level recovery is facilitated by minimising losses. For example, prioritising irrigation on crops that give the highest financial return helps to reduce the financial losses from drought [33].

Providing advance warning of water-related risks can also help farmers to take pre-emptive action to minimise the financial impact (e.g., moving stock from land that will flood or changing the choice of crop or variety in advance of a drought). Although warning times may be effective for quick onset events (like floods) providing sufficient, reliable advance warning of droughts in notoriously difficult. As a consequence, farmers are reluctant to make changes that they know will lead to reduced returns, and the uncertainty over future extreme weather affects farmers' decision-making [18]. The development of widespread participation in water abstractor groups in areas prone to water shortages permits growers to cooperatively determine voluntary abstraction reductions at a catchment scale when water shortages are forecast. This assists in planning and prioritising irrigation, helps balance the distribution of losses between agricultural enterprises and helps to ensure that water use for agriculture does not lead to environmental damage to the catchment when flows are low. Equally, facilitating formal water trading or informal sharing in catchments can ensure that scarce water resources are sensibly distributed between enterprises according to needs, particularly during times of resource stress. Both options illustrate how imbuing water users with the autonomy to self-organise at the catchment level can result in greater resilience to water shortages for agriculture whilst aquatic health is preserved [67].

The final option is to re-orientate the farming system, i.e., to move from a system that is more vulnerable to one that is less vulnerable to water-related risks. This could incorporate a range of incremental changes from changing the type of crops grown to switching into a new form of farming (from horticulture to livestock production, for example), or at the most extreme, switching out of agriculture altogether to engage in a more viable pursuit relative to the risks being faced. Transformation is increasingly recognised as a potentially necessary mode of agricultural adaptation to the more extreme conditions production systems are likely to encounter as climate change progresses [68]. But from a resilience perspective, the need to undergo a transformational shift should be viewed as an opportunity to reconfigure systems in desirable ways, rather than as a failure of the old system to withstand shocks [3]. Such shifts are likely to be unavoidable due to the impacts of larger scale cycles of global environmental change. Thus, it is therefore key that agricultural producers identify ways to facilitate shifts onto sustainable and desirable alternative pathways [1]. For example, growers may undertake preparations to facilitate smaller scale transformations, selecting more drought tolerant crops (or varieties) which could allow a rain fed farm to continue production at the same level in the 
face of increasing droughtiness, whilst moving from rain fed to irrigated cropping would constitute a greater degree of transformation that may deliver a more sustainable livelihood for producers.

Resilience strategies carry costs. These include capital investment costs (e.g., a farm reservoir, efficient drinking water infrastructure), operational costs (e.g., soil management), or profits foregone (e.g., reduced cropped area), so the benefits of the investment will not be realised in all years. Small, family farms may have limited capacity to adapt [12] and are more likely to adopt practices that allow them to save money in all years [18]. Businesses with high investment capital at stake may select risk-averse options that minimize the regret [12]. Factors which facilitate adaptation $[12,18,42]$ include:

- Supporting education and knowledge transfer. Farmers are more willing to adopt practices with which they are already familiar and have been proven to be effective.

- Grants, subsidies, or tax breaks for capital investment in technologies for water efficiency and climate adaptation.

- Water user associations or abstractor groups providing opportunities for collective action.

- Legislative enablers which promote adaptation by providing more flexible regulation at the catchment scale.

- Payments for environmental services and the conservation of natural resources.

- Collaborative funding of science and technology to enhance adaptation.

\section{Conclusions}

The latest climate change scenarios for the UK suggest an increase in water-related risks to agriculture and food production, through changes in the frequency and/or severity of rainfall deficits, restrictions on water abstraction, failure of private water supplies, excess soil water, and fluvial flood risk.

The resilience of the primary production system to changes in water-related risks may be affected by the inherent physical properties of the catchment (e.g., the natural soil hydrology and hydrogeology that affects water storage and the partitioning of effective rainfall between fast and slow flow paths; the presence or absence and hydrological functioning of aquifers) and the concentration or intensity of agricultural production.

The actions that farmers can take to increase resilience to these risks can be categorised as reducing the probability of the risk, increasing robustness, facilitating recovery and adaptation, and re-orienting or even transforming the production system. Predominantly, the water-related risks reviewed cause an irreversible loss of production potential. Consequently, if measures to reduce the probability of the event are prohibitively expensive, farmers are primarily concerned with strategies to build robustness or to reduce the impact of the shock reduced through facilitated recovery. Most decisions about actions or investments to increase resilience to water-related risks are taken at the farm level and are influenced by perceived costs and benefits of change, in the context of current and future climate perceptions. This leads to enhanced specified resilience, but can result in declining general resilience to larger scale, more uncertain water risks. Fostering collaborative partnerships or 'working together', whether among farmers, between farmers and the regulator, or between farmers and the supply chain, allows for more optimal allocation of a resource during times of scarcity to increase headroom, e.g., by trading of water licences, or to facilitate recovery. Policy support to enhance capacities in agriculture to build general resilience by enhancing cross-scale interactions, learning opportunities and catchment-scale autonomy will be key to ensuring the agricultural system can build adaptive and transformational capacity in preparation for the more extreme water-related risks to which it will be subject in the coming decades.

Author Contributions: Conceptualization, T.H., J.K., and I.H.; writing-original draft preparation, review and editing, T.H., J.K., I.H., and C.S.; project administration, T.H.; funding acquisition, T.H. All authors have read and agreed to the published version of the manuscript. 
Funding: This research was funded by the Environment Agency and the Global Food Security's 'Resilience of the UK Food System Programme', with support from BBSRC, ESRC, NERC and Scottish Government under grant no. BB/N020499/1.

Data Access: No new data were generated in the preparation of this review.

Conflicts of Interest: The authors declare no conflict of interest.

\section{References}

1. Boltz, F.; LeRoy Poff, N.; Folke, C.; Kete, N.; Brown, C.M.; St. George Freeman, S.; Matthews, J.H.; Martinez, A.; Rockström, J. Water is a master variable: Solving for resilience in the modern era. Water Secur. 2019, 8. [CrossRef]

2. IPCC. Managing the Risks of Extreme Events and Disasters to Advance Climate Change Adaptation; Field, C.B., Barros, V., Stocker, T.F., Dahe, Q., Eds.; Cambridge University Press: Cambridge, UK, 2012; ISBN 9781139177245.

3. Folke, C.; Carpenter, S.R.; Walker, B.; Scheffer, M.; Chapin, T.; Rockström, J. Resilience thinking: Integrating resilience, adaptability and transformability. Ecol. Soc. 2010, 15. [CrossRef]

4. Carpenter, S.; Walker, B.; Anderies, J.M.; Abel, N. From Metaphor to Measurement: Resilience of What to What? Ecosystems 2001, 4, 765-781. [CrossRef]

5. Brown, I.; Thompson, D.; Bardgett, R.; Berry, P.; Crute, I.; Morison, J.; Morecroft, M.; Pinnegar, J.; Reeder, T.; Topp, K. Chapter 3: Natural Environment and Natural Assets. In UK Climate Change Risk Assessment 2017: Evidence Report; Report Prepared for the Adaptation Sub-Committee of the Committee on Climate Change; Committee on Climate Change: London, UK, 2016.

6. Parsons, D.J.; Rey, D.; Tanguy, M.; Holman, I.P. Regional variations in the link between drought indices and reported agricultural impacts of drought. Agric. Syst. 2019, 173, 119-129. [CrossRef]

7. UKMO. UKCP18 Science Overview Executive Summary; UKMO: Exeter, UK, 2019.

8. Watts, G.; Battarbee, R.W.; Bloomfield, J.P.; Crossman, J.; Daccache, A.; Durance, I.; Elliott, J.A.; Garner, G.; Hannaford, J.; Hannah, D.M.; et al. Climate change and water in the UK-Past changes and future prospects. Prog. Phys. Geogr. 2015, 39. [CrossRef]

9. Helfgott, A. Operationalising systemic resilience. Eur. J. Oper. Res. 2018, 268, 852-864. [CrossRef]

10. Wilhite, D.A.; Glantz, M.H. Understanding: The Drought Phenomenon: The Role of Definitions. Water Int. 1985, 10, 111-120. [CrossRef]

11. Keay, C.A.; Jones, R.J.A.; Hannam, J.A.; Barrie, I.A. The implications of a changing climate on agricultural land classification in England and Wales. J. Agric. Sci. 2014, 152, 23-37. [CrossRef]

12. Knox, J.; Morris, J.; Hess, T. Identifying future risks to UK agricultural crop production: Putting climate change in context. Outlook Agric. 2010, 39, 249-256. [CrossRef]

13. El Chami, D.; Daccache, A. Assessing sustainability of winter wheat production under climate change scenarios in a humid climate-An integrated modelling framework. Agric. Syst. 2015, 140, 19-25. [CrossRef]

14. Daccache, A.; Keay, C.; Jones, R.J.A.; Weatherhead, E.K.; Stalham, M.A.; Knox, J.W. Climate change and land suitability for potato production in England and Wales: Impacts and adaptation. J. Agric. Sci. 2012, 150, 161-177. [CrossRef]

15. Cho, K.; Falloon, P.; Gornall, J.; Betts, R.; Clark, R. Winter wheat yields in the UK: Uncertainties in climate and management impacts. Clim. Res. 2012, 54, 49-68. [CrossRef]

16. Anglian Water. Water, Water Everywhere? Encouraging Collaborating and Building Partnerships; Anglian Water: Huntigdon, UK, 2013.

17. Akande, K.; Hussain, S.; Knox, J.; Hess, T.; Hooftman, D.; Stratford, C.; Schafer, S.; Acreman, M.; Edwards, F. The Impacts of Drought in England; R\&D Technical Report WT0987/TR; Department for Environment, Food and Rural Affairs Water Availability Division: London, UK, 2013.

18. Rial-Lovera, K.; Davies, W.P.; Cannon, N.D. Implications of climate change predictions for UK cropping and prospects for possible mitigation: A review of challenges and potential responses. J. Sci. Food Agric. 2017, 97, 17-32. [CrossRef] [PubMed]

19. Semenov, M.A. Impacts of climate change on wheat in England and Wales. J. R. Soc. Interface 2009, 6, 343-350. [CrossRef] 
20. Christy, B.; Tausz-Posch, S.; Tausz, M.; Richards, R.; Rebetzke, G.; Condon, A.; McLean, T.; Fitzgerald, G.; Bourgault, M.; O'Leary, G. Benefits of increasing transpiration efficiency in wheat under elevated $\mathrm{CO}_{2}$ for rainfed regions. Glob. Chang. Biol. 2018, 24, 1965-1977. [CrossRef]

21. Stanek-Tarkowska, J.; Czyz, E.A.; Dexter, A.R.; Sławiński, C. Effects of reduced and traditional tillage on soil properties and diversity of diatoms under winter wheat. Int. Agrophys. 2018, 32, 403-409. [CrossRef]

22. Johnston, A.E. Soil organic matter, effects on soils and crops. Soil Use Manag. 1986, 2, 97-105. [CrossRef]

23. Eden, M.; Gerke, H.H.; Houot, S. Organic waste recycling in agriculture and related effects on soil water retention and plant available water: A review. Agron. Sustain. Dev. 2017, 37. [CrossRef]

24. Green, T.R.; Ahuja, L.R.; Benjamin, J.G. Advances and challenges in predicting agricultural management effects on soil hydraulic properties. Geoderma 2003, 116, 3-27. [CrossRef]

25. Hess, T.M.; Holman, I.P.; Rose, S.C.; Rosolova, Z.; Parrott, A. Estimating the impact of rural land management changes on catchment runoff generation in England and Wales. Hydrol. Process. 2010, 24, 1357-1368. [CrossRef]

26. Rey, D.; Holman, I.P.; Daccache, A.; Morris, J.; Weatherhead, E.K.; Knox, J.W. Modelling and mapping the economic value of supplemental irrigation in a humid climate. Agric. Water Manag. 2016, 173, 13-22. [CrossRef]

27. DEFRA. Water Usage in Agriculture and Horticulture. Results from the Farm; Business Survey 2009/10 and the Irrigation Survey 2010; Department for Environment, Food and Rural Affairs: London, UK, 2011.

28. Parliament of the United Kingdom. Water Resources Act; Parliament of the United Kingdom: London, UK, 1991.

29. Knox, J.W.; Morris, J.; Weatherhead, E.K.; Turner, A.P. Mapping the financial benefits of sprinkler irrigation and potential financial impact of restrictions on abstraction: A case-study in Anglian Region. J. Environ. Manag. 2000, 58, 45-59. [CrossRef]

30. Salmoral, G.; Rey, D.; Rudd, A.; de Margon, P.; Holman, I. A Probabilistic Risk Assessment of the National Economic Impacts of Regulatory Drought Management on Irrigated Agriculture. Earths Futur. 2019, 7, 178-196. [CrossRef]

31. Knox, J.W.; Hurford, A.; Hargreaves, L.; Wall, E. Climate Change Risk Assessment for the Agriculture Sector; Defra Project Code GA0204; Department for Environment, Food and Rural Affairs: London, UK, 2012.

32. Rio, M.; Rey, D.; Prudhomme, C.; Holman, I.P. Evaluation of changing surface water abstraction reliability for supplemental irrigation under climate change. Agric. Water Manag. 2018, 206, 200-208. [CrossRef]

33. Rey, D.; Holman, I.P.; Knox, J.W. Developing drought resilience in irrigated agriculture in the face of increasing water scarcity. Reg. Environ. Chang. 2017, 17, 1527-1540. [CrossRef]

34. Perry, C. Efficient irrigation; inefficient communication; flawed recommendations. Irrig. Drain. 2007, 56, 367-378. [CrossRef]

35. Hess, T.M.; Knox, J.W. Water savings in irrigated agriculture: A framework for assessing technology and management options to reduce water losses. Outlook Agric. 2013, 42. [CrossRef]

36. Gadanakis, Y.; Bennett, R.; Park, J.; Areal, F.J. Improving productivity and water use efficiency: A case study of farms in England. Agric. Water Manag. 2015, 160, 22-32. [CrossRef]

37. Grafton, R.Q.; Williams, J.; Perry, C.J.; Molle, F.; Ringler, C.; Steduto, P.; Udall, B.; Wheeler, S.A.; Wang, Y.; Garrick, D.; et al. The paradox of irrigation efficiency. Science 2018, 361, 748-750. [CrossRef]

38. ADAS. Water for Irrigation. Ministry of Agriculture; Fisheries and Food Reference Book 202; HMSO: London, UK, 1977.

39. Hess, T.M.; Knox, J.W.; Kay, M.G.; Weatherhead, E.K. Managing the Water Footprint of Irrigated Food Production in England and Wales. In Sustainable Water; Issues in Environmental Science and Technology, 31; Hester, R.E., Harrison, R.M., Eds.; Royal Society of Chemistry: London, UK, 2010; pp. 78-92, ISBN 978-1-84973-225-3.

40. Weatherhead, E.K.; Knox, J.W.; Daccache, A.; Morris, J.; Groves, S.; Hulin, A.; Kay, M.G. Water for Agriculture: Collaborative Approaches and On-Farm Storage; FFG1112 Final Report; Cranfield University: Cranfield, UK, 2014.

41. Rey, D.; Pérez-Blanco, C.D.; Escriva-Bou, A.; Girard, C.; Veldkamp, T.I.E. Role of economic instruments in water allocation reform: Lessons from Europe. Int. J. Water Resour. Dev. 2019, 35, 206-239. [CrossRef]

42. Holman, I.P.; Trawick, P. Developing adaptive capacity within groundwater abstraction management systems. J. Environ. Manag. 2011, 92, 1542-1549. [CrossRef] [PubMed] 
43. Tyrrel, S.F.; Knox, J.W.; Burton, C.H.; Weatherhead, E.K. Assuring the Microbiological Quality of Water Used to Irrigate Salad Crops: An Assessment of the Options Available; Horticultural Development Council Report FV 248; Cranfield University: Cranfield, UK, 2004.

44. DEFRA. Water Usage on Farms. Results from the Farm; Business Survey, England 2015/16; Department for Environment, Food and Rural Affairs: London, UK, 2017.

45. King, J.; Tiffin, D.; Drakes, D.; Smith, K.; Weatherhead, E.K. Water Use in Agriculture: Establishing a Baseline; Defra Project WU0102; Department for Environment, Food and Rural Affairs: London, UK, 2006.

46. Knox, J.W.; Rickson, R.J.; Weatherhead, E.K.; Hess, T.M.; Deeks, L.K.; Truckell, I.J.; Keay, C.A.; Brewer, T.R.; Daccache, A. Provision of Research to Develop the Evidence Base on Soil Erosion and Water Use in Agriculture; Cranfield University for the Adaptation Sub-Committee; Cranfield University: Cranfield, UK, 2015.

47. DWI. Legislation of Private Water Supplies and Drought; Drinking Water Inspectorate: London, UK, 2012.

48. DEFRA. Identification and Knowledge Transfer of Novel and Emerging Technology with the Potential to Improve Water Use Efficiency within English and Welsh Agriculture; Defra Project WU0123; Department for Environment, Food and Rural Affairs: London, UK, 2009.

49. Holman, I.P.; Hollis, J.M.; Bramley, M.E.; Thompson, T.R.E. The contribution of soil structural degradation to catchment flooding: A preliminary investigation of the 2000 floods in England and Wales. Hydrol. Earth Syst. Sci. 2003, 7, 755-766. [CrossRef]

50. Jones, M.R.; Fowler, H.J.; Kilsby, C.G.; Blenkinsop, S. An assessment of changes in seasonal and annual extreme rainfall in the UK between 1961 and 2009. Int. J. Climatol. 2013, 33, 1178-1194. [CrossRef]

51. Fowler, H.J.; Ekström, M. Multi-model ensemble estimates of climate change impacts on UK seasonal precipitation extremes. Int. J. Climatol. 2009, 29, 385-416. [CrossRef]

52. Guillod, B.P.; Jones, R.G.; Dadson, S.J.; Coxon, G.; Bussi, G.; Freer, J.; Kay, A.L.; Massey, N.R.; Sparrow, S.N.; Wallom, D.C.H.; et al. A large set of potential past, present and future hydro-meteorological time series for the UK. Hydrol. Earth Syst. Sci. 2018, 22, 611-634. [CrossRef]

53. ADAS. Development of a Database of Agricultural Drainage; Defra Project ES0111; ADAS: London, UK, 2002.

54. Posthumus, H.; Morris, J.; Hess, T.M.; Neville, D.; Phillips, E.; Baylis, A. Impacts of the summer 2007 floods on agriculture in England. J. Flood Risk Manag. 2009, 2, 182-189. [CrossRef]

55. Morris, J.; Brewin, P. The impact of seasonal flooding on agriculture: The spring 2012 floods in Somerset, England. J. Flood Risk Manag. 2014, 7, 128-140. [CrossRef]

56. Twining, S. Impact of 2014 Winter Floods on Agriculture in England; ADAS report for Defra; ADAS: London, UK, 2014.

57. Alfieri, L.; Dottori, F.; Betts, R.; Salamon, P.; Feyen, L. Multi-model projections of river flood risk in Europe under global warming. Climate 2018, 6, 6. [CrossRef]

58. Roca, M.; Sayers, P.; Bast, H.; Flikweert, J.; Panzeri, M.; Ogunyoye, F.; Hess, T.M.; Young, R. Developing the Evidence Base to Describe the Flood Risk to Agricultural Land in England and Wales; R\&D Technical Report FD2634/TR; Department for Environment, Food and Rural Affairs: London, UK, 2010.

59. Folke, C. Resilience: The emergence of a perspective for social-ecological systems analyses. Glob. Environ. Chang. Policy Dimens. 2006, 16, 253-267. [CrossRef]

60. Cabel, J.F.; Oelofse, M. An indicator framework for assessing agroecosystem resilience. Ecol. Soc. $2012,17$. [CrossRef]

61. Allison, H.E.; Hobbs, R.J. Resilience, adaptive capacity, and the "lock-in trap" of the Western Australian agricultural region. Ecol. Soc. 2004, 9. [CrossRef]

62. Lin, B.B. Resilience in Agriculture through Crop Diversification: Adaptive Management for Environmental Change. Bioscience 2011, 61, 183-193. [CrossRef]

63. Rotz, S.; Fraser, E.D.G. Resilience and the industrial food system: Analyzing the impacts of agricultural industrialization on food system vulnerability. J. Environ. Stud. Sci. 2015, 5, 459-473. [CrossRef]

64. D'Odorico, P.; Laio, F.; Ridolfi, L. Does globalization of water reduce societal resilience to drought? Geophys. Res. Lett. 2010, 37, 1-5. [CrossRef]

65. Abson, D.J.; Fraser, E.D.G.; Benton, T.G. Landscape diversity and the resilience of agricultural returns: A portfolio analysis of land-use patterns and economic returns from lowland agriculture. Agric. Food Secur. 2013, 2. [CrossRef]

66. Holling, C.S. Understanding the complexity of economic, ecological, and social systems. Ecosystems 2001, 4, 390-405. [CrossRef] 
67. Leathes, W.; Knox, J.W.; Kay, M.G.; Trawick, P.; Rodriguez-Diaz, J.A. Developing UK farmers' institutional capacity to defend their water rights and effectively manage limited water resources. Irrig. Drain. 2008, 57, 322-331. [CrossRef]

68. Rickards, L.; Howden, S.M. Transformational adaptation: Agriculture and climate change. Crop. Pasture Sci. 2012, 63, 240-250. [CrossRef] 